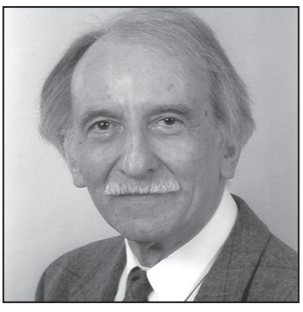

Helmut Kury

Professor emeritus

University of Freiburg

\title{
Harsh Punishment or Alternatives: Which is the Better Crime-prevention?
}

\section{Introduction}

Empirical studies over the past few decades have repeatedly shown that traditional solutions to crime problems - i.e., strict punishments - do not substantially reduce the conflicts caused by crime. Against this background, historical practices such as mediation and restorative justice have re-emerged ${ }^{*}$. R. London has characterised the shift thus: 'Restorative justice as both a philosophy and an implementation strategy developed from the convergence of several trends in criminal justice: the loss of confidence in rehabilitation and deterrence theory, the rediscovery of the victim as a necessary party, and the rise of interest in community-based justice. ${ }^{*}$ Concentrating on harsh punishment of offenders while ignoring the background for the criminal behaviour and the needs of victims of crimes, using them only as witnesses during court proceedings, is less effective in crime prevention than 'alternatives' are. ${ }^{* 3}$ Advocates of mediation and restitution in the aftermath of crime often refer to historical examples. ${ }^{*} 4$ Intensive, sweeping regulation of restitution in most cultural regions seems to be a generally identifiable phenomenon. As S. Sharpe points out, "[r]eparation has been a vehicle for justice throughout human history.".

Just a few years ago, John Braithwaite, one of the fathers of contemporary restorative justice, wrote: 'Of all the great institutions passed down to western civilization by the Enlightenment, none has been a greater

1 See, for example, K.J. Hopt, F. Steffek (eds). Mediation. Rechtstatsachen, Rechtsvergleich, Regelungen. Tübingen, Germany: Mohr Siebeck 2008; G. Johnstone, D.W. Van Ness. Handbook of Restorative Justice. Cullompton: Willan 2007; E. Weitekamp, H.-J. Kerner. Restorative Justice: Theoretical Foundations. Cullompton; Portland, Oregon: Willan 2002; DOI: https://doi. org/10.4324/9781843924838; F. Dünkel et al. (eds). Restorative Justice and Mediation in Penal Matters: A Stock-taking of Legal Issues, Implementation Strategies and Outcomes in 36 European Countries (2 volumes). Mönchengladbach, Germany: Forum-Verlag Godesberg 2015; H. Kury, A. Kuhlmann. Mediation in Germany and Other Western Countries. Forthcoming (2017).

2 R. London. Crime, Punishment, and Restorative Justice: From the Margins to the Mainstream. London; Boulder, Colorado: First Forum Press 2011, p. 13.

3 H. Kury. Zur (Nicht-)Wirkung von Sanktionen - Ergebnisse internationaler empirischer Untersuchungen. - Soziale Probleme 24 (2013), pp. 1-41; H. Kury, A. Scherr (eds). Zur (Nicht-)Wirkung von Sanktionen. Immer härtere Strafen immer weniger Kriminalität? Centaurus Verlag 2013.

4 L. Frühauf. Wiedergutmachung zwischen Täter und Opfer. Eine neue Alternative in der strafrechtlichen Sanktionspraxis. Gelsenkirchen, Germany: Verlag Dr. Mannhold 1988, p. 8.

5 S. Sharpe. The idea of reparation. - G. Johnstone, D.W. Van Ness (eds). Handbook of Restorative Justice. Cullompton: Willan 2007, pp. 24-40 (see p. 26 in particular). 
failure than the criminal justice system. ${ }^{* * 6} \mathrm{He}$ compared it to, as one example, medicine, concluding, as F. McElrea has, that the criminal justice system 'has been less adaptive than other institutions, less responsive to transformations to the environment in which it operates. ${ }^{*}{ }^{*}$ Braithwaite points to the (re-)emergence of restorative justice as one such reform capable of being evidence-based and more responsive. According to L. Walgrave, the difference between restorative justice and criminal justice can be seen especially in the following distinguishing characteristics:

Crime in restorative justice is defined not as a transgression of an abstract legal disposition, but as social harm caused by the offence. In criminal justice, the principal collective agent is the state, while collectivity in restorative justice is mainly seen through community. The response to crime is not ruled by a top-down imposed set of procedures but by a deliberative bottom-up input from those with a direct stake in the aftermath. ${ }^{*}$

In many instances, this approach has shown itself to be successful through lower recidivism rates, redressing of the victims' grievances through addressing their material and financial needs, healing for the communities involved, and fostering of a greater sense of overall satisfaction with the process among the participants. ${ }^{* 9}$

International empirical research shows clearly that most victims, with the possible exception of some of those victimised via very serious crimes, are more interested in restitution for the harm caused than they are in severe punishment of the offender. ${ }^{* 10}$ Yet the predominant government reaction to crime is organised in a way that disregards these needs of the majority of victims and of broad segments of the population who are more concerned with restoration of peace in society and with reduction in the conflicts caused by crime. In this context, mediation and restorative justice can help to bridge the gaps between opposing interests. D.M. Gromet states:

Restorative justice presents a different approach to achieving justice than the traditional court system. Whereas court systems depend on punitive measures and do not attend to victim concerns, restorative justice focuses on repairing the harm caused by an offense, bringing the offender back into society, and giving all actors affected by the crime (the offender, the victim and the community) a direct voice in the justice process. ${ }^{*}{ }^{11}$

Central for the acceptance of mediation and restorative justice in a society is that its structure, process, and opportunities be understood well by the population and by the penal institutions, especially the judges and the courts. ${ }^{*} 2$ G. Johnstone and D.W. Van Ness point out in this context: 'Yet, despite its growing familiarity in professional and academic circles, the meaning of the term "restorative justice" is still only hazily understood by many people. ${ }^{*}{ }^{13}$

6 J. Braithwaite. Foreword. - D. Cornwell et al. (eds). Civilizing Criminal Justice: An International Restorative Agenda for Penal Reform. Hook: Waterside Press 2013, pp. 11-14 (on p. 12).

7 F. McElrea (2013). Restorative justice as procedural revolution: Some lessons from the adversary system. - D. Cornwell et al. (eds). Civilizing Criminal Justice: An International Restorative Agenda for Penal Reform. Hook: Waterside Press 2013, pp. 81-115 (p. 12).

8 L. Walgrave. Integrating criminal justice and restorative justice. - G. Johnstone, D.W. Van Ness (eds). Handbook of Restorative Justice. Cullompton: Willan 2007, pp. 559-579 (on p. 559).

9 H. Kury. Mediation, restorative justice and social reintegration of offenders: The effects of alternative sanctions on punishment. - H. Kury et al. (eds). Women and Children As Victims and Offenders: Background, Prevention, Reintegration. Suggestions for Succeeding Generations, Vol. 2. Springer International Publishing Switzerland 2016, pp. 249-282. DOI: https://doi.org/10.1007/978-3-319-28424-8.

10 K. Sessar. Wiedergutmachen oder Strafen. Einstellungen in der Bevölkerung und der Justiz. Pfaffenweiler, Germany: Centaurus-Verlagsgesellschaft 1992; K. Sessar. Restitution or punishment: An empirical study on attitudes of the public and the justice system in Hamburg. - Eurocriminology 8 (1995), pp. 199-214.

11 D.M. Gromet. Psychological perspectives on the place of restorative justice in criminal justice systems. - M.E. Oswald et al (eds). Social Psychology of Punishment of Crime. Chichester: Wiley-Blackwell 2009, pp. 39-54 (on p. 40).

12 H. Kury, A. Kuhlmann (see Note 1).

13 G. Johnstone, D.W. Van Ness. The meaning of restorative justice. - G. Johnston, D.W. Van Ness (eds). Handbook of Restorative Justice. Cullompton: Willan 2007, pp. 5-23 (p. 6). 


\section{Developments in Germany}

In the middle of the previous century, after having long been consigned to oblivion ${ }^{* 14}$, mediation, along with its positive effects, became a subject of international discussion again, mainly thanks to the interest created by the newly established discipline of victimology research. ${ }^{.15}$ In the 1980 , German professionals began increasing discussion of mediation, against the background of reports from the United States about the successful, time-saving, cost-effective, and also peace-finding application of this approach. ${ }^{*}{ }^{* 16} \mathrm{In}$ the decade that followed, mediation was discussed as if it were an omnipotent method, capable of resolving conflicts related to all kinds of quarrels and problems. Today this method is solidly established, and in the more seasoned modern view it is regarded as an important measure for resolving conflicts. However, the potential of the method is still far from being fully utilised, as has been pointed out by experts. ${ }^{* 17}$

The German Criminal Code (Strafgesetzbuch, StGB) mentions the subject of restitution (Wiedergutmachung) twice, once with regard to duties in the context of probation (in \$56b of Part 2) and the second time in the context of a definition of punishment (in $\$ 46$ of Part 2). On 15 December 1999, the German government implemented the Gesetz zur Förderung der außergerichtlichen Streitbeilegung, a law to enhance conflict resolution outside the courts. With this law, victim-offender restitution (termed 'TOA') became an official part of the penal procedure. ${ }^{* 18}$ Germany's Juvenile Court Act (Jugendgerichtsgesetz, abbreviated 'JGG') places education squarely at its centre. Already in 1923, the JGG had provided an opportunity for the court to require separate restitution from the offender. From this perspective, restitution or mediation plays a central role because these approaches allow the offender to understand the negative impact of his or her crime clearly by listening directly to the experiences of the victim(s). Thus the juvenile-court system introduced the idea of restitution and victim-offender mediation early on. ${ }^{*} 19$

Today, the procedure for victim-offender restitution remains uniform across the various states of Germany. The following criteria are employed for the application of TOA: it does not encompass petit crimes, there is to be no net widening of social control, the presence of an individual victim is required, the circumstances of the crime must be clearly defined, the offender must have expressed remorse and accepted responsibility for the crime, and both parties (the victim and the offender) must have accepted the prescribed procedure and demonstrated willingness to co-operate. ${ }^{* 20}$ Victim-offender mediation is seen, correctly, as an excellent pedagogic opportunity for the offender and also shows successful incidence of reducing the harm incurred by the victim, yet in practice it was used relatively rarely in Germany until quite recently. More often, courts impose punishments that require the offender to pay fines.

\section{Developments in other European countries}

In collaboration with the German Ministry of Justice, K.J. Hopt and F. Steffek published a reader on mediation, which provides an overview of the current issues related to mediation in Europe and beyond. ${ }^{{ }_{21}}$ The volume presents regulations and research from 19 countries, not limited to European states. ${ }^{{ }^{22}}$ The authors argue that mediation needs to be promoted further as a form of conflict reduction. One important

14 L. Frühauf (see Note 4), p. 63.

15 H.J. Schneider. Viktimologie - Wissenschaft vom Verbrechensopfer. Tübingen, Germany: Mohr 1975.

16 D. Frehsee. Schadenswiedergutmachung als Instrument strafrechtlicher Sozialkontrolle. Berlin 1987; D. Rössner. Die Universalität des Wiedergutmachungsgedankens im Strafrecht. - H.-D. Schwind et al. (eds). Festschrift für Hans Joachim Schneider zum 70. Geburtstag am 14. November 1998. Kriminologie an der Schwelle zum 21. Jahrhundert. Berlin 1998, pp. 877-896. DOI: https://doi.org/10.1515/9783110901542.877; G. Kaiser. Kriminologie. Ein Lehrbuch. Heidelberg, Germany: C.F. Müller 1996, p. $216 f f$.

17 K.J. Hopt, F. Steffek. Mediation - Rechtsvergleich, Regelungsmodelle, Grundsatzprobleme. - K.J. Hopt, F. Steffek (eds). Mediation. Rechtstatsachen, Rechtsvergleich, Regelungen. Tübingen, Germany: Mohr Siebeck 2008, pp. 3-102 (p. 7).

18 G. DeLattre. Der Täter-Opfer-Ausgleich - die Praxis eines anderen Umgangs mit Straftaten. - P. Senghaus (ed.). Mediation und Polizei. Rothenburg \& Oberlausitz, Germany: Sächsische Polizei 2010, pp. 81-102 (p. 90).

19 W. Heinz. Opfer und Strafverfahren. - G. Kaiser et al. (eds). Kleines Kriminologisches Wörterbuch. Heidelberg, Germany: C.F. Müller 1993, pp. 372-377 (p. 376).

20 G. DeLattre (see Note 18), p. 93.

21 K.J. Hopt et al. (see Note 1). See also D. Rössner (see Note 16), p. $881 \mathrm{ff}$.

22 R. Lummer et al. (eds). Restorative Justice - A European and Schleswig-Holsteinian Perspective. Schriftenreihe Soziale Strafrechtspflege, Vol. 1. 2011, pp. 235-242. 
aspect of this is provision of easier access to the law-related process for citizens. Mediation offers several other advantages in addition, among them an opportunity for more effective conflict resolution, increased support for the parties involved, constructive approaches to reduction of crime, decreasing of the burden faced by courts (i.e., case overloads), and a reduction in costs for all parties - including the state. ${ }^{{ }^{2} 3}$

Hopt and Steffek emphasise the clear differences in the procedure for mediation from one country to the next. These are not surprising when one considers the considerable variation in definitions of the concept and the differences in legal culture. ${ }^{* 24}$ The theory clearly lays out that co-operation on a voluntary basis is a key element of mediation, but some states nevertheless discuss the question of whether the parties may be forced to co-operate under certain circumstances. In addition, the role of the mediator is defined differently - for example, with regard to whether he or she is allowed to offer suggestions and possible solutions. Alongside their use in a penal connection, mediation and victim-to-offender restitution are used more and more for extralegal problems, such as family matters (for example, during resolution of conflicts related to divorce), problems in school, and workplace disputes.

While they display differences in several respects, the definitions of mediation in various countries concentrate on four elements: the presence of conflict, the voluntary nature of the action, systematic support of communication between the parties, and a solution that has been identified by the parties with the support of a mediator who has no decision-making power. The positive impact of mediation can be seen in all societies where the procedure is focused on the social conflict and in which the legal regulation is limited to serving a supportive function. All legal systems accept that mediation is intended not for spontaneous or arbitrary support but for the facilitation of communication between the individual parties by experts. Confidentiality of the procedure and neutrality of the mediator play a central role in the success of this process. ${ }^{*} 25$ International studies have found that the training of mediators differs greatly between countries. ${ }^{*}{ }^{* 6}$ Only a few countries have clearly specified training programmes. Similarly, there is great variety internationally in the professional groups active as mediators.

S. Tränkle compares the German Täter-Opfer-Ausgleichs-Verfahren (victim-offender mediation procedure) with the French model of Médiation Pénale with regard to adult criminal law and the probability of implementation under the conditions of the respective penal procedure. She critically discusses the realworld probability of implementing mediation with the current conditions under the traditional penal procedure. She points out that mediators have to accomplish a difficult task - namely, transformation of the traditional criminal-court procedure into one that can offer a chance for effective mediation. Mediation, according to her study, is hindered when the parties act with a focus on the penal procedure. The orientation of the parties toward their role in the traditional penal procedure is not an opportune starting point for open conversation. The potential for open conversation has to be clarified before the actual mediation can begin. Proceeding from this background, Tränkle comes to the conclusion that a structural 'docking to the penal procedure' hinders the development of mediation. The influence of the traditional penal procedure on the shaping of mediation cannot be excluded, because the practice itself is dominated by attention to the law. Hence, Tränkle argues that mediation can lead only partly, if at all, to transcending the realm of the traditional criminal-court procedure. ${ }^{* 27}$

In consideration of their experiences of co-operating with Eastern European countries, J. Willemsens and Walgrave point to problems and oppositions such as 'a highly punitive attitude among the public and policy makers, an uncritical reliance on incarceration, strong resistance within law enforcement, prosecutors and judges who fear competition from alternatives, a passive civil society and weakened public legitimacy of the state and its institutions, limited trust in NGOs and in their professional capacities, lack of information about restorative justice and restorative justice pilots, low economic conditions making it difficult to set up projects, lack of a tradition of co-operation and dialogue in several sectors and professions, a general loss of trust in a better future and a mood of despondency and cynicism, forms of nepotism and

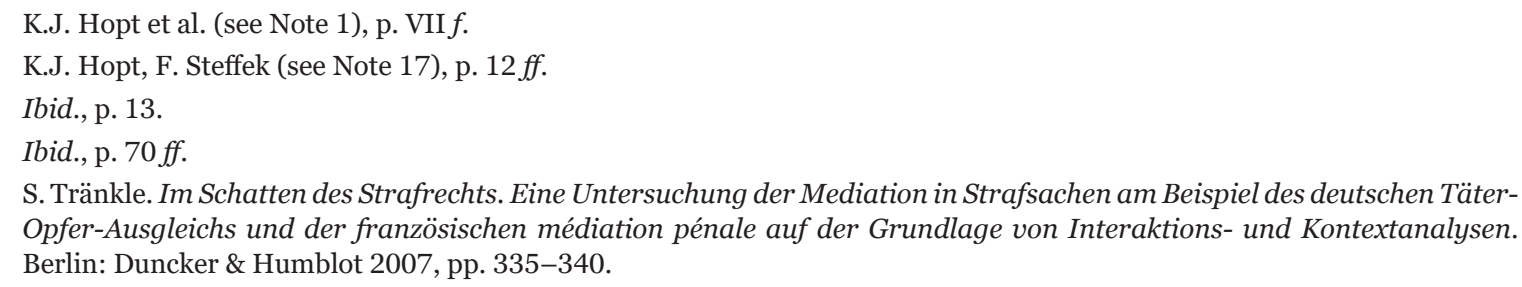


even corruption in parts of the criminal justice system, heavy administrative and financial constraints on the agencies preventing investment in qualitative work. ${ }^{{ }{ }^{2} 8}$

Meanwhile, mediation has become an international phenomenon and is used in Germany and other Western countries not only in criminal- or civil-law cases but also to address other conflicts, such as controversies within families ${ }^{* 29}$, in schools ${ }^{*} 30$, in the workplace, within communities ${ }^{*} 31$, between commercial companies ${ }^{*} 32$, in the police force ${ }^{*} 33$, and within prisons ${ }^{*} 34$. But overall it can be said that it is within criminal justice that [mediation] is fast becoming most influential. ${ }^{*}{ }^{35}$

The Ministry of Justice for England and Wales reports in a press release from 14 March 2013 that mediation will be used to aid in couples' separation procedures. The UK government strongly supports mediation, which represents a quicker, simpler, and more effective way for couples who are separating to agree on how to divide their assets or arrange contact with children, one that avoids the traumatic and divisive effects of courtroom battles. The Ministry of Justice included in its annual budget 25,000,000 pounds sterling to support mediation programmes in this field and develop new binding legislation stipulating that couples 'must consider mediation to sort out the details of their divorce' before going to court. The main advantages are seen in reduction of costs and time: According to the Ministry of Justice, " $[t]$ he average cost of resolving property and financial disputes caused by separation is approximately $£ 500$ through mediation for a publicly funded client, compared to $£ 4,000$ for issues settled through the courts. The average time for a mediated case is 110 days compared to 435 days for non-mediated cases'. ${ }^{*} 6$

B. Morrison discusses mediation programmes in schools, concluding: 'As the field of restorative justice began to define itself in the 1990s, the role of schools in promoting restorative justice was seen as central to developing a more restorative society as a whole. ${ }^{*} 37$ Today, there are many programmes, internationally, that focus on developing social and emotional intelligence in schools, in the sense conceived of by, for example, L.W. Sherman, who sees restorative justice as 'emotionally intelligent justice'. ${ }^{*} 8$ Evaluations have shown positive results, 'that the use of restorative measures, across a range of levels, is an effective alternative to the use of suspensions and expulsions'. ${ }^{39}$

Van Ness writes about mediation programmes in United States prisons in, for example, the context of 'victim awareness and empathy programmes' but also for the resolution of conflicts between inmates and prison staff. ${ }^{* 0}$ In some programmes, victims or stand-ins for them are included, while in others the immediate victims do not participate. ${ }^{*} 41$ The use of restorative justice and victim-offender mediation in

28 J. Willemsens, L. Walgrave. Europe. - G. Johnstone, D.W. Van Ness (eds). Handbook of Restorative Justice. Cullompton: Willan 2007, pp. 488-499 (p. 491).

29 B. Bannenberg et al. Mediation bei Gewaltstraftaten in Paarbeziehungen. Baden-Baden, Germany, 1999.

30 B. Morrison. Schools and restorative justice. - G. Johnstone, D.W. Van Ness (eds). Handbook of Restorative Justice. Cullompton: Willan 2007, pp. 325-351.

31 K. McEvoy, H. Mika. Restorative justice and the critique of informalism in Northern Ireland. - British Journal of Criminology 42 (2002), pp. 534-562. DOI: https://doi.org/10.1093/bjc/42.3.534.

32 R. Young. Testing the limits of restorative justice: The case of corporate victims. - C. Hoyle, R. Young (eds). New Visions of Crime Victims. Oxford; Portland, Oregon: Hart Publishing 2002, pp. 133-172. DOI: https://doi.org/10.5040/9781472559258. ch-006.

33 P. Senghaus (ed.). Mediation und Polizei. Rothenburg \& Oberlausitz, Germany: Sächsische Polizei 2010.

34 A.-K. Sasse. Einbindung der Mediation in die Gerichtsbarkeit. Gerichtliche Mediation in Strafvollzugssachen - ein Projekt. Hamburg: Dr. Kovac 2010.

35 S. Green. The victims' movement and restorative justice. - G. Johnstone, D.W. Van Ness (eds). Handbook of Restorative Justice. Cullompton: Willan 2007, pp. 171-191 (p. 183).

36 UK Ministry of Justice. More mediation encouraged as divorce hotspots are revealed. Press release of 20.2.2013, London. Available at https://www.gov.uk/government/news/more-mediation-encouraged-as-divorce-hotspots-are-revealed (most recently accessed on 19.7.2017); UK Ministry of Justice. Moving family mediation forward. Press release of 14.3.2013, London. Available at https://www.gov.uk/government/news/moving-family-mediation-forward (most recently accessed on 19.7.2017).

37 B. Morrison (see Note 30), p. 325.

38 L.W. Sherman. Reason for emotion: Reinventing justice with theories, innovation, and research. - Criminology 41 (2003), pp. 1-38. DOI: https://doi.org/10.1111/j.1745-9125.2003.tb00980.x.

39 B. Morrison (see Note 30), p. 340.

40 D.W. Van Ness. Prisons and restorative justice. - G. Johnstone, D.W. Van Ness (eds). Handbook of Restorative Justice. Cullompton: Willan 2007, pp. 312-324 (p. 314).

41 See, with reference to Germany, discussion of a similar programme in Hamburg: O. Hagemann. Restorative justice in prison? - L. Walgrave (ed.). Repositioning Restorative Justice. Cullompton: Willan 2003, pp. 218-231 (p. 225). 
European prisons is on the increase in some countries, Belgium and Germany among them. For Belgium, we can look to the research by K. Buntinx. ${ }^{*} 42$

With some programmes, the main aim is reconciliation of the inmate with his or her family members or preparation of the community for the re-entry of the prisoner after release. In 'prison-community programmes', the interest is in reducing the separation between inmate and community, a very important element for successful reintegration after release. Of special importance too is the reduction of 'prisonisation'. Van Ness explains: 'Prison subcultures are typically deviant, making rejection of deviance more difficult for prisoners. Inviting them to participate in a process of restoration and transformation requires tremendous strength on their part to move against the prevailing culture [...]. Prisons use or threaten physical and moral violence, making adoption of peaceful conflict resolution difficult." 43 Very often, offenders were themselves victims of violent crimes, as children or juveniles. According to several authors, more attention should be paid to victims in modern prison systems. ${ }^{*} 4$

\section{Results from empirical evaluation of mediation}

Until a few years ago, findings from empirical research and evaluation of mediation, including restorative justice, on the international level have been quite scarce. In recent years, this body of literature has expanded greatly, and research shows overwhelming evidence of 'the positive impact of restorative practices at multiple levels, with case types ranging from first-time offenders and misdemeanants to more serious chronic and violent offenders' ${ }^{*} 45$ Authors argue that, in contrast to empirical research into treatment programmes for offenders, whose outcomes are not uniformly successful, studies documenting the positive results of restorative justice programmes are more consistent in their findings: 'Most studies of restorative programmes, including recent meta-analyses indicate some positive impact [...], and some suggest that restorative programmes may have equal or stronger impacts than many treatment programmes. ${ }^{*} 46$

Comparative studies analysing recidivism after participation in victim-offender restitution programmes relative to that seen with traditional penal procedure have been carried out primarily in the USA, Great Britain, and Australia. ${ }^{*} 47$ Restorative justice is a broad concept, with procedures varying widely between programmes, and these programmes, in turn, may be used in different parts of the penal procedure. The development of experimental studies is often impossible, a factor that might reduce the results' validity. In addition, the criteria for judging recidivism are often not clearly defined; this reduces comparability significantly. ${ }^{*} 48$ Against this background, H. Hayes presents the following summary of the outcomes: 'Despite results that show restorative justice effects no change [...] or in some cases is associated with increase in offending [...], the weight of the research evidence on restorative justice and reoffending seems tipped in the positive direction to show that restorative justice has crime reduction potential.' He does not make a 'definitive claim about restorative justice's ability to prevent crime because, at this stage, we simply do not know enough about how and why restorative justice is related to offenders' future behaviour'. However,

42 K. Buntinx. Victim-offender mediation in homicide cases: Opportunities and risks. Unpublished presentation for the European Society of Criminology in Tübingen, Germany, in 2012.

43 D.W. Van Ness (see Note 40), p. 319; see also C. Gelber. Viktimologische Ansätze im Strafvollzug. - Monatsschrift für Kriminologie und Strafrechtsreform 95 (2012), pp. 441-450.

44 C. Gelber (see Note 43), p. 447.

45 G. Bazemore, L. Ellis (2007). Evaluation of restorative justice. - G. Johnstone, D.W. Van Ness (eds). Handbook of Restorative Justice. Cullompton: Willan 2007, pp. 397-425 (p. 397); see also H. Hayes. Reoffending and restorative justice. - G. Johnstone, D.W. Van Ness (eds). Handbook of Restorative Justice. Cullompton: Willan 2007, pp. 426-444.

46 J. Bonta et al. Quasi-experimental evaluation of an intensive rehabilitation supervision program. - Criminal Justice and Behavior 27 (2000), pp. 312-329; DOI: https://doi.org/10.1177/0093854800027003003; W. Nugent et al. Participation in victim-offender mediation and the prevalence of subsequent delinquent behavior: A meta-analysis. - Utah Law Review 2003, pp. 137-166.

47 H. Hayes (see Note 45), p. 433.

48 H. Kury. Die Behandlung Straffälliger. Teilband I: Inhaltliche und methodische Probleme der Behandlungsforschung. Berlin: Duncker \& Humblot 1986; C. Menkel-Meadow. Restorative Justice: What is it and does it work? - Annual Review of Law and Social Science 2007, 3, pp. 161-187. DOI: https://doi.org/10.1146/annurev.lawsocsci.2.081805.110005. 
he continues, he does wish to suggest that, "on balance, restorative justice "works"." 49 This approach can contribute to reductions in recidivism, but, he notes, 'post-intervention experiences are important', as J. Latimer et al. have written when describing their meta-analyses: 'Although restorative programs were found to be significantly more effective, these positive findings are tempered by an important self-selection bias inherent in restorative justice research. ${ }^{*} 50$

Latimer and S. Kleinknecht point out the following:

In general, empirical research into restorative justice is arguably still in its infancy. Numerous questions remain unanswered. There are several issues, however, that do appear to be resolved. Victims who experience a restorative justice program express high levels of satisfaction with the process and the outcomes. Victims also believe that the process is fair. There are strong indications that victims are much less satisfied within the traditional court system [...]. Offenders also express high levels of satisfaction with restorative justice programming and perceive the process to be fair. In addition, research suggests that offenders processed by the traditional system are less satisfied. There is evidence, though, that the severity of the restitution agreement is closely related to an offenders' [sic] satisfaction level. The harsher the restitution, the more likely an offender will express dissatisfaction with the program. Most restorative justice program participants have a high level of success in negotiating restitution agreements. There is also an indication that a high proportion of offenders referred to restorative justice programs follow through on their agreements and are more likely to comply than are offenders with court-ordered restitution. ${ }^{*}{ }^{51}$

The most frequent criticism of restorative justice focuses on the possible problem of a reduction in, or detrimental effect on, the deterrent impact of (harsh) punishment. However, proponents of restorative justice point out in this regard that deterrence has not been proved to have substantive effects. ${ }^{*} 2$ 'It is of course true that the deterrent effects of punishment tend to be greatly overestimated and its tendency to re-enforce criminality underestimated. However, the average citizen will probably find this response unconvincing, because the idea that without penal sanctions for law-breaking, many people will succumb to temptations to break the law seems self-evident to most people,' states Johnstone. ${ }^{*} 33$ This emphasises the necessity of educating the public about mediation and its greater success, in many circumstances, in resolving conflicts in various branches of society and addressing the impacts of crime.

\section{Final discussion}

An overview of international publications on mediation and restorative justice in European countries shows that the body of literature has grown vastly, especially with regard to Western industrial societies. Since the end of WWII and in a process accelerating in the 1960s and 1970s, legitimate discussion about more comprehensive ways to include the interests of victims in criminal prosecution has promoted the rediscovery and rapid growth in importance of victimology. In traditional, state-regulated penal procedures, the victims' role is limited to that of witness - compensation for the harm they have suffered is seen as their personal problem. Traditional criminal law is not concerned with the victims' needs and instead focuses solely on the sanctioning of offenders. In light of this, it is not surprising that many victims are unsatisfied with the results of the penal procedure. They have only the 'satisfaction' that the offender is punished, more or less severely. This result, in turn, promotes a desire for harsh punishment. ${ }^{*} 4$

4 H. Hayes (see Note 45), p. 440.

50 J. Latimer et al. The effectiveness of restorative justice practices: A meta-analysis. - The Prison Journal 85 (2005), pp. 127-144 (p. 127).

51 J. Latimer, S. Kleinknecht. The Effects of Restorative Justice Programming: A Review of the Empirical. Department of Justice, Canada: Research and Statistics Division 2000, p. 16.

52 H. Kury, E. Shea (eds). Punitivity: International Developments (3 volumes). Bochum, Germany: Universitätsverlag Dr. Brockmeyer 2011.

53 G. Johnstone. Critical perspectives on restorative justice. - G. Johnstone, D.W. Van Ness (eds). Handbook of Restorative Justice. Cullompton: Willan 2007, pp. 598-614 (p. 601).

54 H. Kury et al. (see Note 1); H. Kury, J. Obergfell-Fuchs. Punitiveness - impacts and measurements. - H. Kury, E. Shea (eds). Punitivity: International Developments, Vol. 2: Insecurity and Punitiveness. Bochum, Germany: Universitätsverlag Dr. Brockmeyer 2011, pp. 165-209. 
Modern penal policy is predominantly focused on the restoration of 'penal peace' (the German concept is Rechtsfrieden), which does not automatically re-create social peace. ${ }^{*} 55$ With penal peace, the primary concentration is on control and the prestige of penal law, which means that social peace has to be promoted separately. This includes an effort to avoid shifting the problem to the criminal act alone and look instead at its origins to find a more all-encompassing, holistic solution. Interpersonally oriented regulations have positive effects on socialisation and peace in a society, and once the people understand this, the role of pure criminal justice per se can be reduced.

R. Young points out that, according to the British Crime Survey (BCS), even in 1984, 51\% of the victims interviewed said that they would be willing to meet the offender outside the courtroom, accompanied by an official 'helper', to speak about restitution. Answering a question formulated slightly differently in the BCS of $1998,41 \%$ of the respondents accepted a meeting with the offender, in the presence of a third party, to ask questions about the background of the crime and to have an opportunity to tell the offender about the effects of the victimisation. ${ }^{*}{ }^{6}$ As A. Sanders emphasises, research has shown that if offenders understand the penal procedure and perceive it as legitimate, they also accept the result more readily, even in cases wherein they perceive the outcome to be unjust. The same is true for the victims. ${ }^{*}{ }^{57}$ Hopt and Steffek underscore that, if we are to advance as a society, the culture of reducing conflicts in a given society has to be promoted via clear information being supplied to judges, prosecutors, and especially the public. ${ }^{*} 58$

London summarises the positive results and the challenges associated with restorative justice thus:

Restorative justice is a bold and thought-provoking innovation that has engaged the energies and excited the hopes of criminal justice reformers throughout the world over the last several decades. And yet, while it has achieved outstanding results in thousands of programs, it has remained a marginal development because it has failed to articulate a theory and set of practice applicable to serious crimes and adult offenders. ${ }^{*} 9$

He points out that all parties profit from successful mediation:

For the victim, the restoration of trust approach offers the prospect of genuine repair for the material and emotional harm [...]. For the community, the restoration of trust offers the prospect of involvement in problem solving toward the goal of achieving safety and resolving ongoing conflicts. For the offender, the restoration of trust approach enhances the likelihood of regaining acceptance into the moral community of law-abiding people by the demonstration of accountability both for the material losses and the moral transgression involved in the crime. ${ }^{* 60}$

All modern systems of penal law are confronted with the question of how, if at all, to integrate victimoffender restitution into the systems. International comparison by D. Rössner indicates that restitution should be included in all systems of criminal justice. ${ }^{*}$ As the victims themselves report positive effects in most cases, mediation cannot be accused of - in line with a criticism commonly directed at them - exploiting victims to bring healing to offenders. Rather, it is a measure with positive effects on both parts: for offenders and victims alike.

Initially, mediation was established to help victims, to improve their condition in the wake of the victimisation and to give them better chances of receiving restitution for the damages. The plethora of research results now available shows clearly that this aim can be reached if the measure is taken in a professional manner. Most victims find that their situation has improved after participation in mediation and that they have gained greater chances of overcoming the harm caused by the crime than with classical penal procedures.

55 K. Sessar. Wiedergutmachen oder Strafen. Einstellungen in der Bevölkerung und der Justiz (see Note 10), p. 21.

56 R. Young (see Note 32), p. 137.

57 A. Sanders. Victim participation in an exclusionary criminal justice system. - C. Hoyle, R. Young (eds). New Visions of Crime Victims. Oxford; Portland, Oregon: Hart Publishing 2002, pp. 197-222 (p. 222). DOI: https://doi. org/10.5040/9781472559258.ch-008.

58 K.J. Hopt et al. (see Note 1), p. 79.

59 R. London (see Note 2), p. 315.

60 Ibid., p. 320.

61 D. Rössner (see Note 16), p. 894. 
Helmut Kury

With respect to the effects on the offenders, especially in terms of their re-socialisation, the results are not as unanimous. This is not surprising. Mediation is usually a brief process, lasting a few hours; therefore, it would be hoping for too much to expect to see long-lasting effects on offenders, especially incarcerated offenders - who often have marked deficits in social skills. Nonetheless, as one part of a comprehensive rehabilitation programme, mediation plays a very important role, and its use should be extended in light of this. The classical approach to criminal justice has obvious disadvantages as far as the reintegration of offenders is concerned, and these shortcomings could be reduced, at least to some extent, via professional mediation. 